\title{
Charleston Harbor Ship Motion Data Collection and Squat Analysis
} US Army Corps of Engineers $s_{\circledast}$

by Michael J. Briggs, Stephen T. Maynord,
Charles R. Nickles, and Terry N. Waller

PURPOSE: This Coastal and Hydraulics Engineering Technical Note (CHETN) documents the field data collection of ship motion data using Global Positioning System (GPS) sensors in Charleston, SC, Harbor during April 1999. Comparisons of measured squat with several empirical predictions are presented and discussed.

BACKGROUND: The U.S. Army Corps of Engineers' (USACE) Coastal and Hydraulics Laboratory (CHL) conducted a field study at Charleston Harbor between April 16, 1999 and April 25, 1999. Prototype data of environmental forces (waves, currents, and water levels) and ship motions during inbound/outbound transits of the deep-draft entrance channel and interior channels were collected. The purpose of this field study was to provide data for (a) validating physical model measurements, (b) enhancing the ship simulator model, and (c) improving USACE design guidance for deep-draft navigation entrance channels. The study was funded by the "Design of Deep-Draft Coastal Navigation Entrance Channels" and the "Depth/Width Requirements for Inland Navigation Channels" work units of the Navigation Systems Research Program.

Charleston was selected for the study because the entrance channel is relatively long and exposed to the wave environment for much of its length. The two-way entrance channel (Figure 1) is $21 \mathrm{~km}$ $(70,000 \mathrm{ft})$ long by $244 \mathrm{~m}(800 \mathrm{ft})$ wide, and $12.8 \mathrm{~m}(42 \mathrm{ft})$ deep $(\mathrm{mllw})$. The data from this study were later used in an idealized physical model of the Charleston Harbor entrance channel. Ship squat is the downward displacement of a ship while underway that is a function of ship draft, hull configuration, and speed, and channel depth, width, and cross-sectional shape. The results of analysis of the ship motions to determine ship squat is presented and compared to several empirical equations.

PROJECT PLANNING: Prior to the start of the survey, CHL personnel met with the Charleston Branch pilots and U.S. Army Engineer District, Charleston, personnel to discuss the project and request assistance. Without the cooperation of the pilots, the project would have been logistically impossible. The pilots agreed to allow the survey crews to ride on the pilot boat and assisted in the selection of vessels and obtaining required permissions.

The USACE operating procedure was to board/disembark with the harbor pilot. On outbound transits the equipment had to be taken down before the end of the channel so that the survey crew could get off the ship with the pilot. On inbound transits the ship was generally in the channel before all the GPS were collecting data. The inbound tracks typically were longer than the outbound tracks.

VESSELS: The primary vessels of interest were container ships and bulk carriers whose length exceeded $213 \mathrm{~m}(700 \mathrm{ft})$. A total of 18 ships were tracked. Their origin (outbound) or destinations 


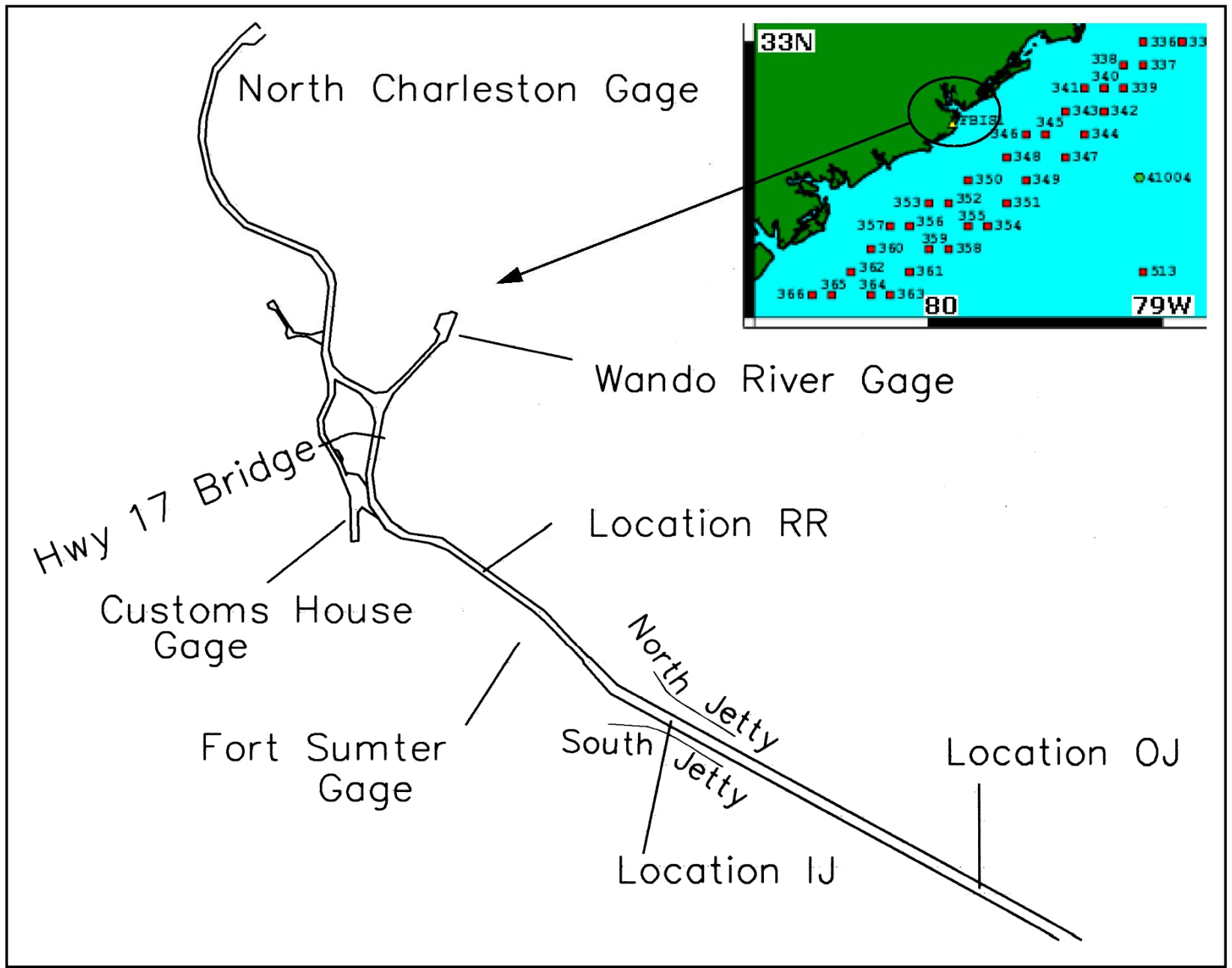

Figure 1. Schematic of Charleston Harbor channel, jetties, gauges, and squat evaluation points

(inbound) were the Wando River terminal, North Charleston, or Columbus Street terminal. Because of data losses and other data collection problems, only 12 vessels were analyzed for vertical excursions. Ship dimensions and parameters for these 12 vessels are listed in Table 1. Figure 2 shows the Brasilia container ship on an inbound transit to Charleston Harbor on 21 April 1999.

ENVIRONMENTAL MEASUREMENTS: Environmental measurements consisted of wave, current, and tide levels during the period of the study. A CHL directional wave gauge and an acoustic current profiler were placed at the midpoint of the portion of the channel outside the jetties. A point current meter was placed near the offshore end of the north jetty. A water level gauge was installed near Fort Sumter. Water level information is particularly important for accurate calculation of squat.

Wave height, period, and direction data for 20-27 April 1999 are presented in Figure 3. In addition to the CHL wave gauge, National Oceanic and Atmospheric Administration (NOAA) sta 41004 buoy measurements are shown. The NOAA 3-m, discus buoy is located $41 \mathrm{n} . \mathrm{m}$. southeast of the entrance 


\begin{tabular}{|c|c|c|c|c|c|c|c|c|}
\hline \multirow[b]{2}{*}{ Vessel } & \multirow[b]{2}{*}{ Type } & \multirow[b]{2}{*}{ Transit } & \multirow{2}{*}{$\begin{array}{l}\text { Length } \\
\text { Overall } \\
\text { (LOA) }\end{array}$} & \multirow[b]{2}{*}{ Beam } & \multicolumn{2}{|c|}{ Bridge to } & \multicolumn{2}{|c|}{ Ship Draft } \\
\hline & & & & & Bow & Stern & Bow & Stern \\
\hline Alligator Liberty & Container & Outbound & 246 & 32.2 & 180.1 & 66.1 & 9.5 & 10.4 \\
\hline MV Aniara & $\mathrm{RO} / \mathrm{RO}$ & Outbound & 196 & 31.7 & N/A & N/A & 7.9 & 9.1 \\
\hline Chetumal & Container & Inbound & 243 & 32.2 & 178.7 & 64.1 & 6.6 & 11.2 \\
\hline Dorothea Rickmers & Container & Outbound & 184 & 25.3 & 166.1 & 18.6 & 7.7 & 9.0 \\
\hline Ever Diamond & Container & Inbound & 294 & 32.2 & 219.6 & 74.5 & 9.5 & 10.6 \\
\hline Golden Farmer & Bulk & Inbound & 188 & 28.0 & 158.0 & 30.0 & 10.1 & 10.1 \\
\hline Gulf Bridge & Container & Inbound & 210 & 32.2 & 145.9 & 64.2 & 8.5 & 9.8 \\
\hline London Maersk & Container & Outbound & 289 & 32.3 & 188.9 & 99.8 & 9.5 & 11.4 \\
\hline Madison Maersk & Container & Inbound & 294 & 32.2 & 194.0 & 100.1 & 9.3 & 9.8 \\
\hline Munkebo Maersk & Container & Inbound & 294 & 32.2 & 194.0 & 100.1 & 11.0 & 11.0 \\
\hline Newark Bay & Container & Inbound & 289 & 32.3 & 244.9 & 44.6 & 10.7 & 10.7 \\
\hline MSC Sabrina & Container & Inbound & 243 & 32.2 & 178.8 & 63.8 & 10.4 & 11.5 \\
\hline
\end{tabular}

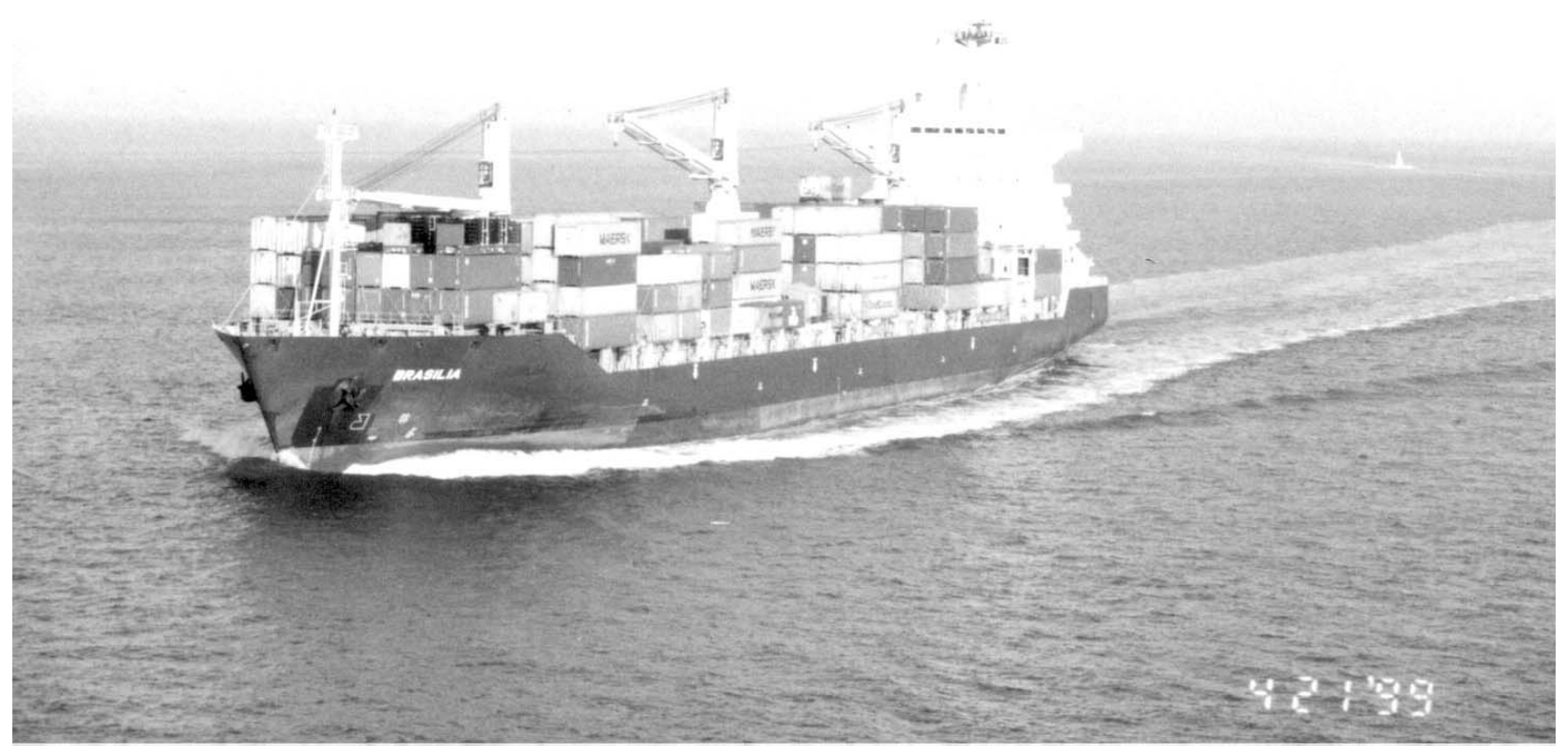

Figure 2. Vessel Brasilia inbound to Charleston Harbor on 21 Apr 99 


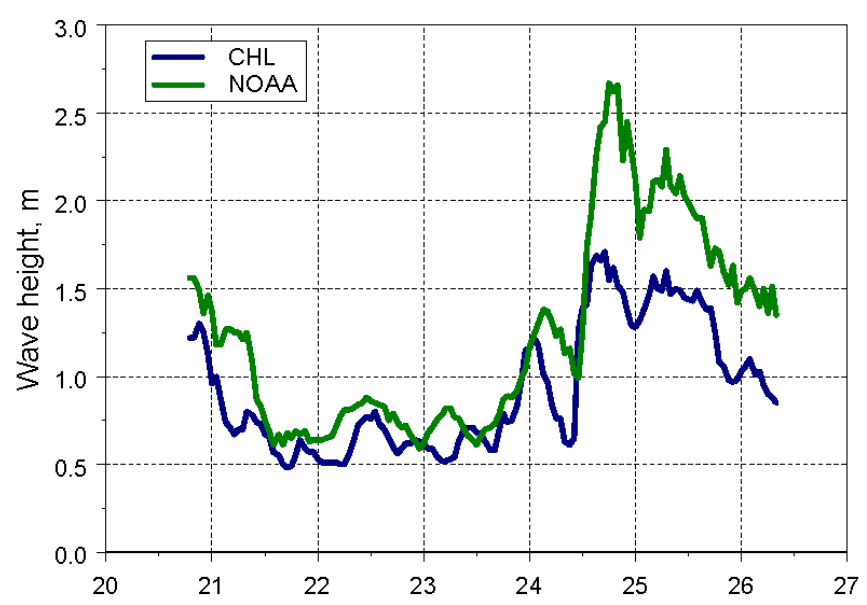

a. Wave height

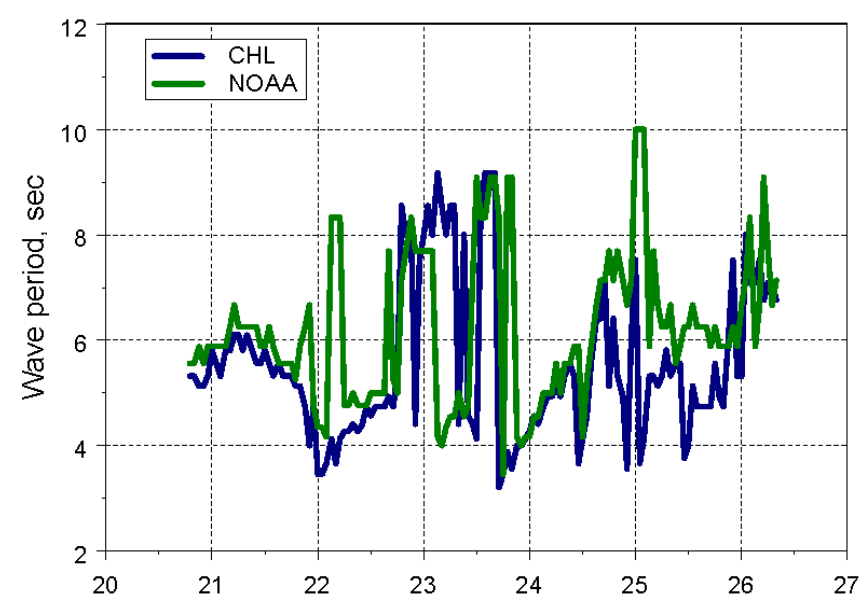

b. Wave period

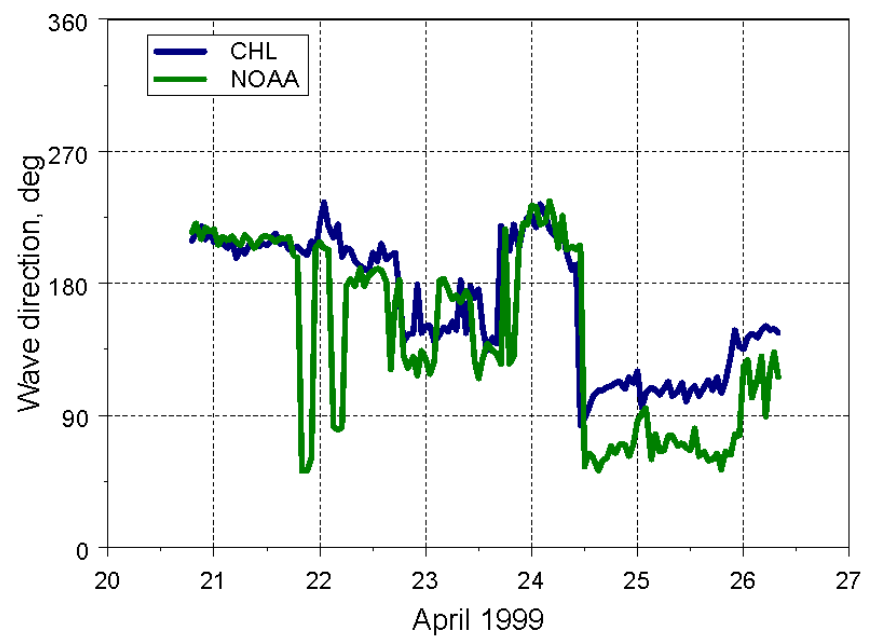

c. Wave direction

Figure 3. Comparison of $\mathrm{CHL}$ and NOAA wave parameters for Charleston Harbor in April 1999 (a) wave height, (b) wave period, and (c) wave direction 
channel in 36.6-m water depth. Although wave transformation occurs as the waves travel from the deeper NOAA location to the shallow-water CHL directional gauge, the comparisons are useful to demonstrate possible ranges of the wave parameters.

During the transit times for the 12 ships from 21-26 April, wave heights at the CHL gauge varied from 0.5 to $1.7 \mathrm{~m}$, with an average of $1 \mathrm{~m}$. Wave periods ranged from 3.5 to $9.2 \mathrm{sec}$, with an average of $5.4 \mathrm{sec}$. Wave directions varied from 83 to $211 \mathrm{deg}$ (direction toward which waves travel, measured clockwise from north), with an average of $156 \mathrm{deg}$. In general, wave conditions were relatively "benign" during this study.

Additional water level information was available at Charleston Harbor from NOAA and the U.S. Geological Survey (USGS). The main NOAA gauge is on the downtown waterfront at the Custom's House. An additional gauge is on the Highway 17 bridge. There was also a gauge where the Interstate crossed both the Cooper River and the Wando River. The USGS did not have elevations on these gauges. However, CHL used GPS to establish elevations on docks at North Charleston and Wando River. Leveling was then used to get water surface elevations at the dock. The data from the water level was used to adjust the elevation of the gauges on the interstate bridges. A gauge at Fort Sumter and one outside the jetties at Folly Island were also used in the analysis.

\section{GLOBAL POSITIONING SYSTEM DATA COLLECTION:}

Global Positioning System. Ship motions were measured with GPS technology and postprocessed using dual-frequency, kinematic survey techniques to obtain the highest possible accuracy of 1-3 cm. GPS surveys of this type have been successfully performed in several ports and rivers over the last few years with little inconvenience to either the pilots or the vessels.

Ship antenna positions were determined using Dual Frequency Trimble 4000 GPS receivers and post-processing kinematic survey techniques. The technique requires two receivers recording observations simultaneously. The receivers synchronize the data collection, depending on the specified rate. The reference receiver (base station) remains fixed on a known control point while the roving receiver (onboard the ship) collects data. The observation data are post-processed by computer to calculate relative vector or coordinate differences. The technique requires that four or more satellites must maintain a constant lock at both receivers to process the data. The processing software outputs the horizontal positions in South Carolina 1927 grid coordinates.

A temporary GPS base station (fixed) was located in a secure area at Fort Johnson during the ship track study. The Fort Johnson site was selected so that data could be collected from the offshore end of the channel to any dock within the harbor. Static GPS survey techniques were used to determine the position of the Fort Johnson base station by using National Geodetic Survey (NGS) published benchmarks in the area. A benchmark at Fort Moultrie was also used during the tracking of several ships.

The procedure for obtaining these measurements required that a three-person survey crew board the vessel and install three GPS antennas near the bow and the port and starboard bridge wings. This process took approximately 10-15 min to complete. The bow antenna was positioned near the forward edge of the bow along the center line of the ship. The bridge antennas were positioned as near as possible to the outside port and starboard edges of the ship. Each antenna was positioned to 
avoid obstructions to satellite signals. Each GPS antenna was mounted on a 2.54-cm (1-in.) diam mast that was easily secured to the vessel with elastic cords. Each antenna position was carefully measured relative to the ship. The bow antenna was measured as the distances aft of the bow and from the center line. The bridge antennas were measured relative to the face of the bridge and the edge of the ship. The antenna height was measured above the deck of the ship. The X-Y-Z locations of the antennas on the 12 ships are listed in Table 2.

\section{Table 2 GPS Antenna Locations}

\begin{tabular}{|c|c|c|c|c|c|c|c|c|c|}
\hline \multirow[b]{2}{*}{ Vessel } & \multicolumn{3}{|c|}{ Bow, m } & \multicolumn{3}{|c|}{ Port, $\mathrm{m}$} & \multicolumn{3}{|c|}{ Starboard, m } \\
\hline & $\mathbf{X}$ & $\mathbf{Y}$ & $\mathbf{Z}$ & $\mathbf{X}$ & $\mathbf{Y}$ & $\mathbf{Z}$ & $\mathbf{X}$ & $\mathbf{Y}$ & $\mathbf{Z}$ \\
\hline Alligator Liberty & 0.00 & -0.49 & 1.30 & -0.94 & 0.13 & 2.36 & -0.94 & 0.13 & 2.29 \\
\hline MV Aniara $^{1}$ & 5.89 & 0.00 & 2.12 & -0.41 & 3.49 & 2.34 & -0.41 & 3.49 & 2.29 \\
\hline Chetumal & -1.04 & 0.84 & 2.15 & -0.46 & 0.12 & 2.30 & -0.36 & 0.12 & 2.19 \\
\hline Dorothea Rickmers & 0.00 & 0.00 & 2.20 & -0.40 & 0.09 & 2.67 & -0.40 & 0.09 & 2.93 \\
\hline Ever Diamond & 0.00 & 0.00 & 2.16 & -8.49 & 0.24 & 1.84 & -8.54 & 0.10 & 2.53 \\
\hline Golden Farmer & 0.08 & 0.59 & 1.83 & 0.55 & 0.56 & 2.29 & 0.51 & 0.55 & 2.19 \\
\hline Gulf Bridge & 0.00 & 0.78 & 2.16 & -0.35 & 2.17 & 1.91 & 0.37 & 0.21 & 2.58 \\
\hline London Maersk & -1.19 & 1.87 & 1.99 & -1.45 & 0.15 & 2.29 & -1.50 & 0.15 & 2.34 \\
\hline Madision Maersk & 0.00 & 0.00 & 0.57 & -0.23 & 0.24 & 2.56 & 0.15 & 0.06 & 1.61 \\
\hline Munkebo Maersk & 0.00 & 0.70 & 2.15 & 0.37 & 0.32 & 1.65 & -0.36 & 0.20 & 2.53 \\
\hline Newark Bay & 0.00 & 0.00 & 2.16 & -2.32 & 0.14 & 2.35 & 0.94 & 1.13 & 2.52 \\
\hline MSC Sabrina & -0.45 & 1.46 & 2.37 & 0.99 & 0.24 & 2.27 & -0.93 & 0.24 & 2.29 \\
\hline
\end{tabular}

The GPS receiver consisted of a logging unit placed in a self-contained backpack with batteries. The data-logging rate was one sample per second (i.e., $1 \mathrm{~Hz}$ ) from the Highway 17 bridge to the end of the entrance channel. Due to memory limitations with the loggers, however, it was set at once every $3 \mathrm{sec}$ (i.e., $0.33 \mathrm{~Hz}$ ) inshore of the Highway 17 bridge.

A problem that arises during ship tracks is that there are times during each day when the satellite coverage is not sufficient to conduct even a static survey, much less a survey where some of the satellites could be periodically blocked by the ship's superstructure. Since it was not possible to request when the ship would transit the channel, there were some data sets that did not obtain centimeter-level accuracy. Another problem occurred near the Highway 17 bridge when some of the GPS signals reflected off the bridge.

Vertical Control. Vertical control was important in the survey. GPS operates on an earth model known as the WGS84 ellipsoid. The Charleston District uses NGVD29 (National Geodetic Vertical Datum, for year 1929 datum) for vertical control in the Charleston area. Water levels and channel depths are referenced to mean lower low water (mllw). The NGS benchmarks were in NAVD88 (North American Vertical Datum, for year 1988 datum). NOAA tidal benchmarks in the area have relationships between mllw and NGVD29. NGVD29 and the new vertical datum NAVD88 are based on gravitational leveling techniques. High accuracy survey work generally discourages transformations between NGVD29 and NAVD88, but there was no choice in this situation. A NGS program called Geoid96 was used to transform elevations between the WGS84 vertical and the NAVD88 vertical. Another program called Vertcon was used to convert elevations from NAVD88 to 
NGVD29. Both of these routines are contained in the USACE program Corpscon. The Geoid96 was used to transform the benchmark elevations around Fort Johnson to ellipsoid heights. All of the ship track data were processed as ellipsoid heights. The Corpscon was then used to convert the data to NGVD29. The conversion process was checked against a NOAA tidal benchmark.

EMPIRICAL SQUAT EQUATIONS: The PIANC (1997) classifies channels as unrestricted shallow water, restricted channel, or canal. Although the Charleston reach has all three types, this analysis focuses on the areas where squat is largest in unrestricted shallow water. Relatively wide channels can be classified as unrestricted shallow-water channels.

The PIANC (1997) lists three empirical equations for predicting ship squat that are applicable for this type of channel cross section. They include equations by (a) Huuska (1976), (b) Barrass (1979, 1981), and (c) Romisch (1989). The equation by Eryuzlu et al. (1994) is also applicable for unrestricted shallow water, but requires block coefficients $C_{b}>0.8$ (i.e., a measure of ship fineness equal to the ratio of the ship's volume divided by an equivalent rectangular volume with the same length, beam, and draft). None of the ships in this study satisfy this last requirement for $C_{b}$, however.

Ship squat is a function of the depth Froude Number $F_{r}$, defined as

$$
F_{r}=\frac{V}{\sqrt{g h}}
$$

where $V$ is ship speed relative to the water, $g$ is gravitational acceleration, and $h$ is water depth.

The first empirical equation for predicting ship squat is by Huuska (1976). It is based on previous work by Guliev (1971) for ship squat at the bow $S_{b}$, and is similar to the equation in ICORELS (1980)

$$
S_{b}=2.4 \frac{\nabla}{L_{p p}^{2}} \frac{F_{r}^{2}}{\sqrt{1-F_{r}^{2}}} K_{s}
$$

where $\nabla$ is ship displacement volume $=C_{b} L^{*} B^{*} T, L$ is overall length of the ship (i.e., LOA) at the waterline, $B$ is the beam, $T$ is draft, and $L_{p p}$ is ship length between perpendiculars. The coefficient $K_{s}$ is defined as

$$
\begin{array}{cc}
K_{s}=7.45 s_{1}+0.76 & \text { for } \mathrm{s}_{1}>0.03 \\
K_{\mathrm{s}}=1 & \text { for } \mathrm{s}_{1} \leq 0.03
\end{array}
$$

and

$$
\mathrm{s}_{1}=\left(\mathrm{A}_{\mathrm{s}} / \mathrm{A}_{\mathrm{ch}}\right) \mathrm{K}_{1}
$$

where $A_{s}$ is the midship cross-sectional area $=0.98^{*} B^{*} T, A_{c h}$ cross-sectional area of the channel, and $K_{1}$ varies with $A_{s} / A_{c h}$ and $T / h$ and is equal to 1 for an unrestricted channel width. Additional information on the calculation of $K_{1}$ is contained in PIANC (1997). 
The second empirical equation is based on work by Barrass $(1979,1981)$ for maximum squat $S_{\max }$

$$
S_{\max }=\frac{C_{b} S_{2}^{2 / 3} V_{k}^{2.08}}{30}
$$

where $S_{2}$ is the blockage ratio $=A_{s} / A_{w}, A_{w}=A_{c h}-A_{s}$, and $V_{k}$ is ship speed relative to water in knots. The final empirical equation is by Romisch (1989) for maximum bow or stern squat $S$

$$
S=C_{V} C_{F} K_{\Delta T} T
$$

where coefficients $C_{V}, C_{F}$, and $K_{\Delta T}$ are defined in the paragraphs that follow. The coefficient $C_{V}$ is defined as

$$
C_{V}=8\left(\frac{V}{V_{c r}}\right)^{2}\left[\left(\frac{V}{V_{c r}}-0.5\right)^{4}+0.0625\right]
$$

For unrestricted shallow water, the critical ship speed $V_{c r}$ is defined as

$$
V_{c r}=0.58\left(\frac{h L}{T B}\right)^{0.125} \sqrt{g h}
$$

For bow squat, $C_{F}$ is defined as

$$
C_{F}=\left(\frac{10 C_{b} B}{L_{p p}}\right)^{2}
$$

and $C_{F}=1$ for stern squat. The coefficient $K_{\Delta T}$ is defined as

$$
K_{\Delta T}=0.155 \sqrt{\frac{h}{T}}
$$

The following assumptions (PIANC 1997) were used in these equations.

a. For ships with different bow and stern draft, the average draft was used in the equations and in the calculation of ship cross-sectional area.

$b$. In the Barrass equation, unrestricted shallow water exists when bottom width $(W)$ is greater than about 8 beam widths $(B)$ of the ship. Although not stated in PIANC (1997), channel cross-sectional area for unrestricted shallow water was assumed to be equivalent to $8^{*} B^{*} h$.

c. The length between perpendiculars and the block coefficient were not known for all ships. If unknown, both parameters were taken from the table of typical values given in PIANC (1997). 
d. Both Huuska and Barrass equations are compared to the maximum of the observed bow or stern squat.

DATA ANALYSIS: The purpose of this CHETN is to calculate ship squat from the GPS measurements and compare to the three empirical equations. Several steps are involved in this process and are discussed in the paragraphs that follow.

a. Convert the GPS antenna measurements using the appropriate datum conversions discussed in the previous section.

$b$. Pre-process the ships according to ship trim considerations.

c. Accurately determine surface-water elevations using measurements and/or numerical model predictions.

d. Correct ship speeds during the transits.

e. Correct ship vertical elevations during the transits.

f. Select sites based on required channel cross section and ship speeds.

Ship Trim Considerations. According to PIANC (1997), large initial trim can affect the squat characteristics of a ship. A reasonable criterion of ships having differences in at-rest bow and stern draft of less than or equal to $1 / 200$ (i.e., 0.5 percent) of the ship length was selected to insure that a sufficient number of ships would be available for analysis. Therefore, the database of 12 ships (Table 1) was limited to six ships: Alligator Liberty, Ever Diamond, Golden Farmer, Munkebo Maersk, Newark Bay, and MSC Sabrina. Two of the vessels, the inbound Munkebo Maersk and the outbound Alligator Liberty, are used as examples of inbound and outbound transits in this CHETN.

Water-Surface Elevation (WSE) Determination. One of the formidable challenges at Charleston Harbor is the relatively large tidal variation that makes an accurate determination of the water-surface elevation (WSE) along the path of the ship very difficult. Tidal variation during the field study was semidiurnal and up to $1.8 \mathrm{~m}$ (6 ft). A two-dimensional (2-D) numerical model (RMA10-2D) existed for the Charleston Harbor reach from an earlier study. The RMA10-2D model is part of the TABS-MD Numerical Modeling System within the Surface-Water Modeling System (SMS). RMA10-2D is a 2-D depth-averaged hydrodynamic, finite element model for free surface flows.

This model was calibrated using observed tides during the field study at the NOAA Customs House gauge (Figure 4) and a reasonable match was obtained for the observed gauge data at Fort Sumter, North Charleston, and Wando River. When available, actual gauge data were used to define the WSE along the ship track because differences between computed water levels and observed water levels were sometimes up to $30 \mathrm{~cm}(1 \mathrm{ft})$. The North Charleston $(\mathrm{NC})$, Customs House $(\mathrm{CH})$, and Wando River (WR) gauge data were used for the at-rest locations of the ships, depending on their berthing location.

Ship Speed. The GPS data gives the ship's true speed (ground speed) and the antenna elevation referenced to NGVD29. To obtain the ship's actual speed relative to the water and the antenna height above the water, the tide-generated velocity and water surface at the ship's location for each point of evaluation were determined. 


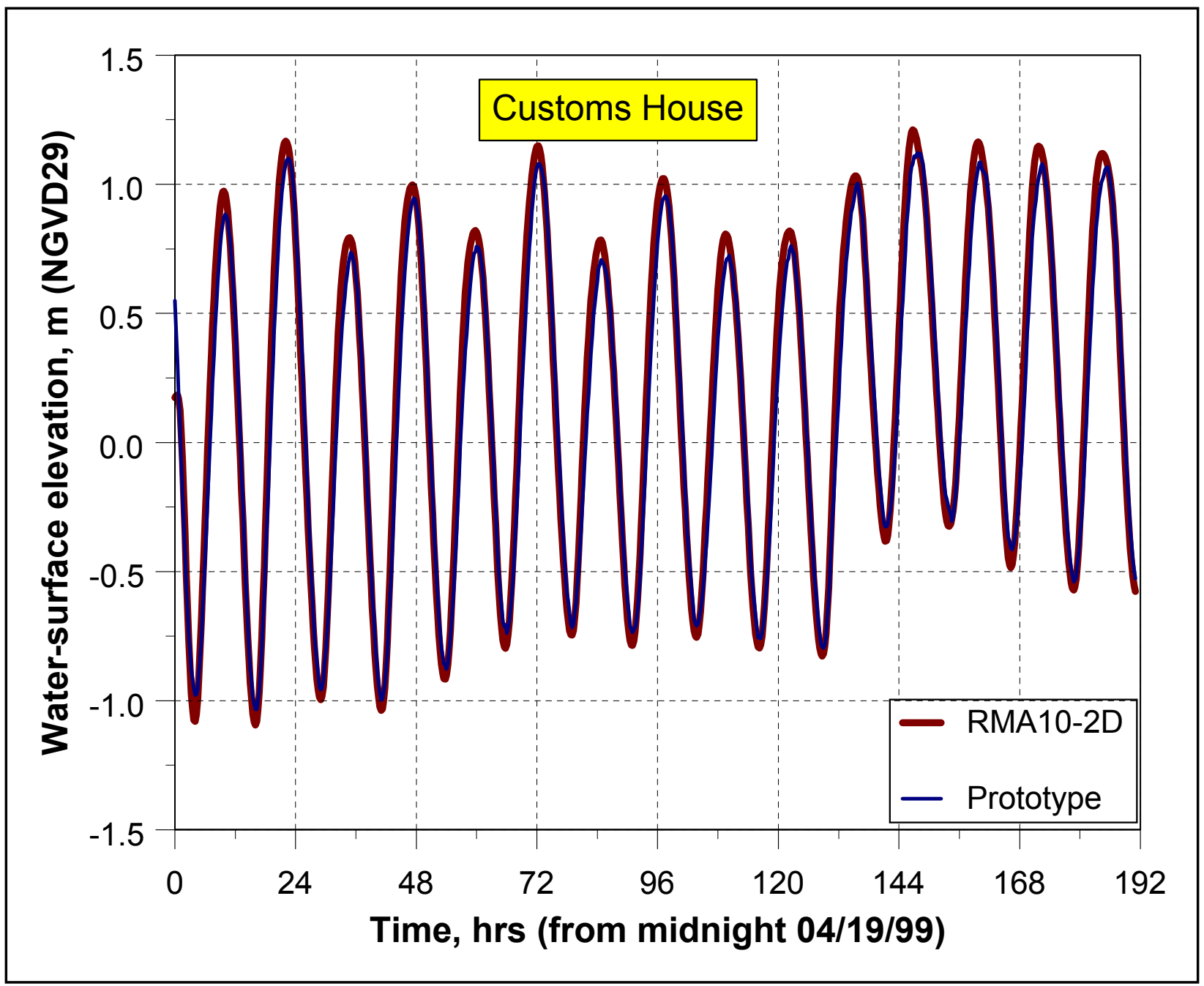

Figure 4. Comparison of measured water level with RMA10-2D predictions at Custom House location

The current velocity components from RMA10-2D were reduced to a magnitude and azimuth measured clockwise from north. For determination of the ship's speed relative to the water, the magnitude of the current velocity was assumed to be inward, outward, or normal to the ship's track based on the azimuth. The ship's speed relative to the water was determined by adjusting the ship's ground speed by adding or subtracting (depending on the direction of ship's travel) the magnitude of the inward or outward current velocity. The magnitude of the current was used to compute the ship's speed relative to the water instead of computing the actual velocity component along the ship's track. This was justified since the magnitude of the current velocities was relatively small (maximum of about $0.9 \mathrm{~m} / \mathrm{sec}(3 \mathrm{ft} / \mathrm{sec})$ ) compared to the ship's speed and the difference between the magnitude and its $\mathrm{x}$ - and $\mathrm{y}$-components was normally small. For current velocities normal to the ship track, the ship's ground speed was used with no adjustments.

The speed of each ship was computed for each time-step (1 or $3 \mathrm{sec})$ and plotted relative to Eastern Standard Time (EST). These calculations were performed for the bow, port, and starboard GPS receivers and are shown in Figure 5 for the two example vessels. These plots were examined and points of evaluation were determined based on relatively constant ship speed and the stability of the 
antenna elevation data. General trends are for decreasing speeds on inbound transits and increasing speeds on outbound transits. Another significant feature is the variation in speed and acceleration at some locations during the transits. These trends make it difficult to fulfill the requirements of the PIANC empirical models.

The ship's location for the bow antenna track is shown in Figure 6 for the Munkebo Maersk and Alligator Liberty. Ship speeds and times of passage at several locations are shown on these plots for reference.

Site Selection Criteria. Sites selected for the squat analysis had to have a relatively constant channel cross section and ship speed for the empirical equations to be applicable. Antenna elevations exhibit a lag in elevation change after a change in ship speed since the water level depression that the ship travels in takes time to reach an equilibrium shape after the ship changes speed. The constant speed criteria led to the requirement that the ship's speed was relatively constant for 5 min prior to the squat evaluation. Three locations (Figure 1) were selected that satisfied the constant channel cross-sectional criteria. They are as follows:
a. Outside the jetties (OJ) at (2388369,313181).
b. Inside the jetties (IJ) at $(2360109,328625)$.
c. Rebellion Reach (RR) at (2342952,342367).

Cross sections at the three locations are shown in Figure 7. Water levels were determined at these locations using the Customs House, Fort Sumter, and Folly Island gauges along with the numerical model output.

Ship Elevations. At each of the analysis locations (plus the at-rest location where squat was zero), the elevations of the three GPS receivers were determined based on 120 -sec averages. The averaging was done to eliminate any ship motions other than squat at the bow and stern on the ship's center line. Figure 8 shows these corrected elevations for the port, starboard, and bow GPS sensors for the Munkebo Maersk and Alligator Liberty. Because of small values, the bow curve is shown with a 12.2-m (40-ft) constant value added to improve readability.

OBSERVED AND PREDICTED SQUAT CALCULATIONS: The "Water Resources Annual Hydrologic Data Report of South Carolina for WY 1999" Web site was used to determine values of specific conductance to define density differences due to salinity differences at pertinent locations in the Charleston Harbor reach. From these data, the North Charleston berthing location on the Cooper River was the only area where specific conductance differences were significantly different from other locations at Charleston Harbor. At North Charleston, specific conductance was about 50 percent of values at the other Charleston Harbor locations during the 21-25 April 1999 field study. Based on 30 parts per million $(1,021 \mathrm{~kg} / \mathrm{cu} \mathrm{m}(63.77 \mathrm{lbs} / \mathrm{cu} \mathrm{ft}))$ being applicable to the all Charleston Harbor areas except the North Charleston area, typical ship block coefficients, and North Charleston having 50 percent of the specific conductance of the other areas; density effects on ship draft amount to about a 1-percent increase in draft at North Charleston due to density effects alone. For average draft of Charleston Harbor ships, this amounts to an increase of about $0.1 \mathrm{~m}(0.3 \mathrm{ft})$. This value was added to the observed squat for the three ships (Ever Diamond, Golden Farmer, and MSC Sabrina) berthing at North Charleston. 


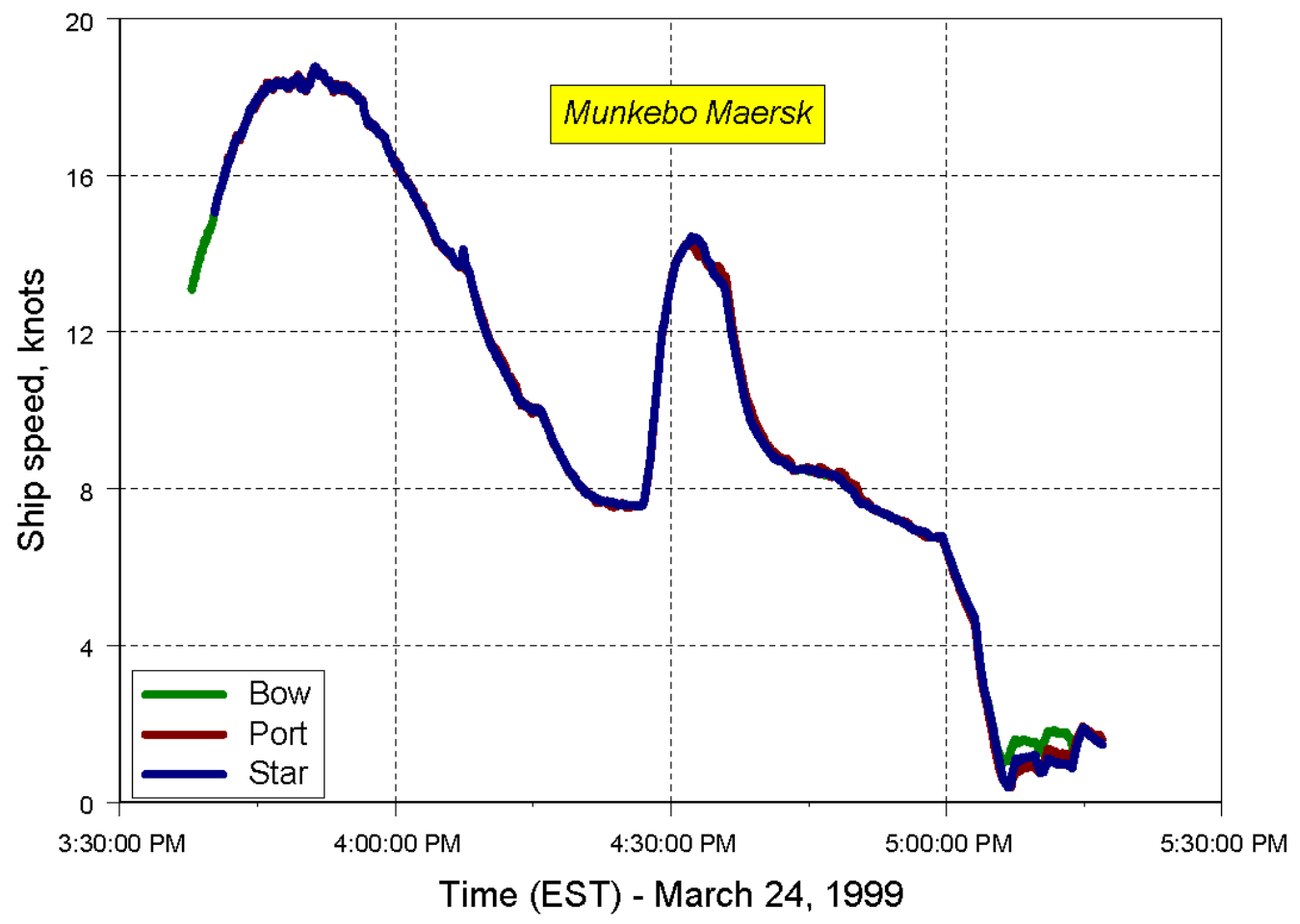

a. Inbound Munkebo Maersk

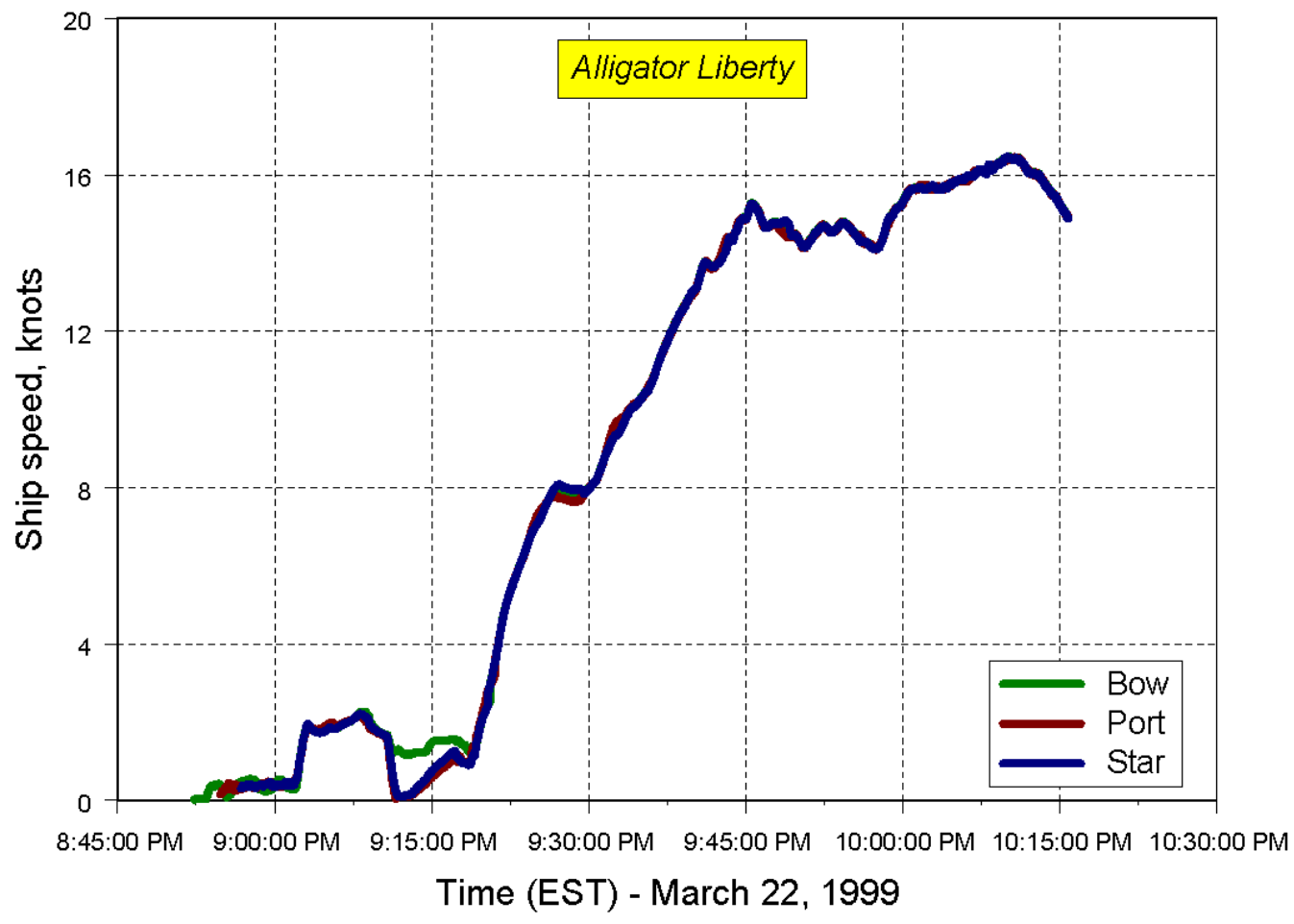

b. Outbound Alligator Liberty

Figure 5. Ship transit speeds 


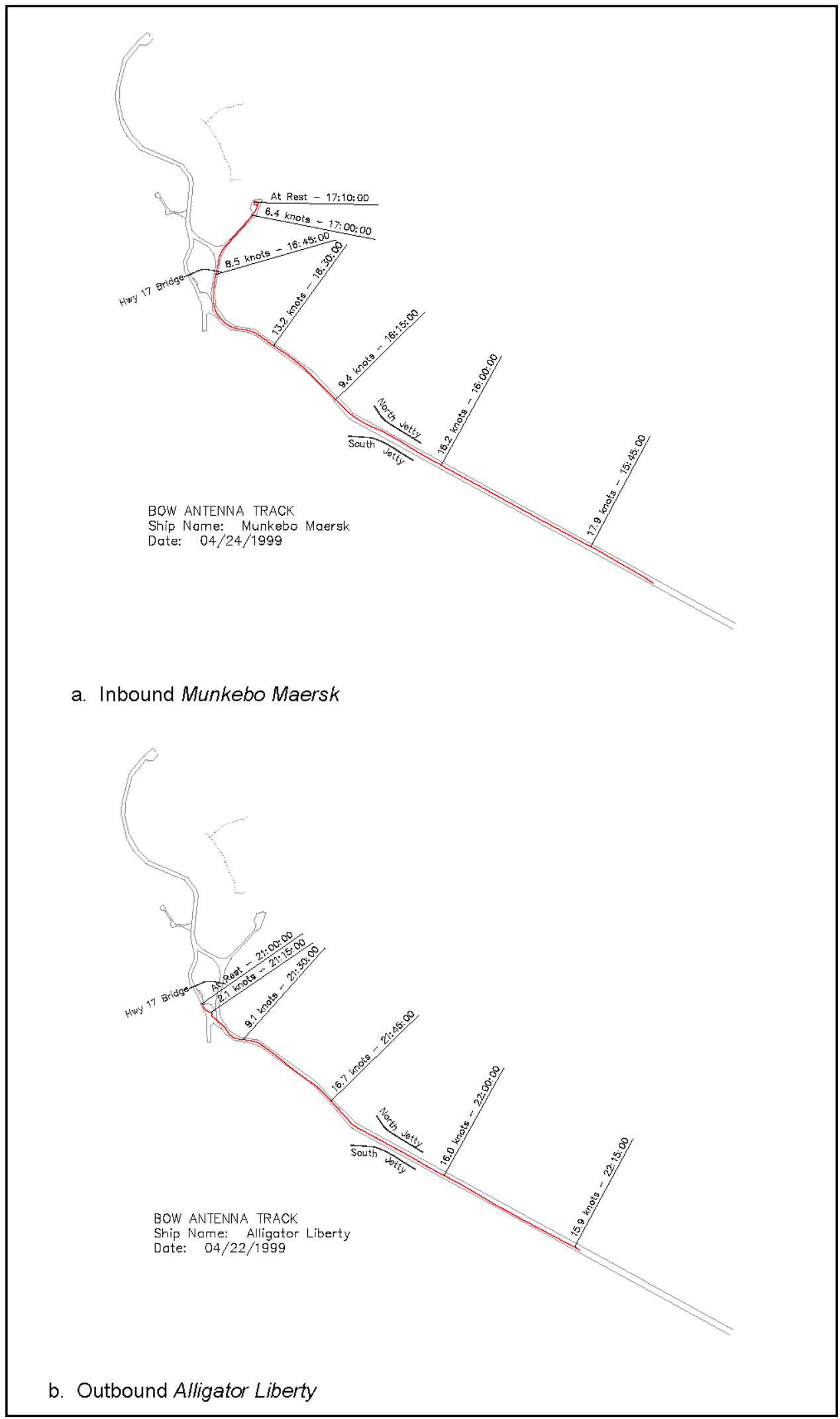

Figure 6. Bow antenna track 


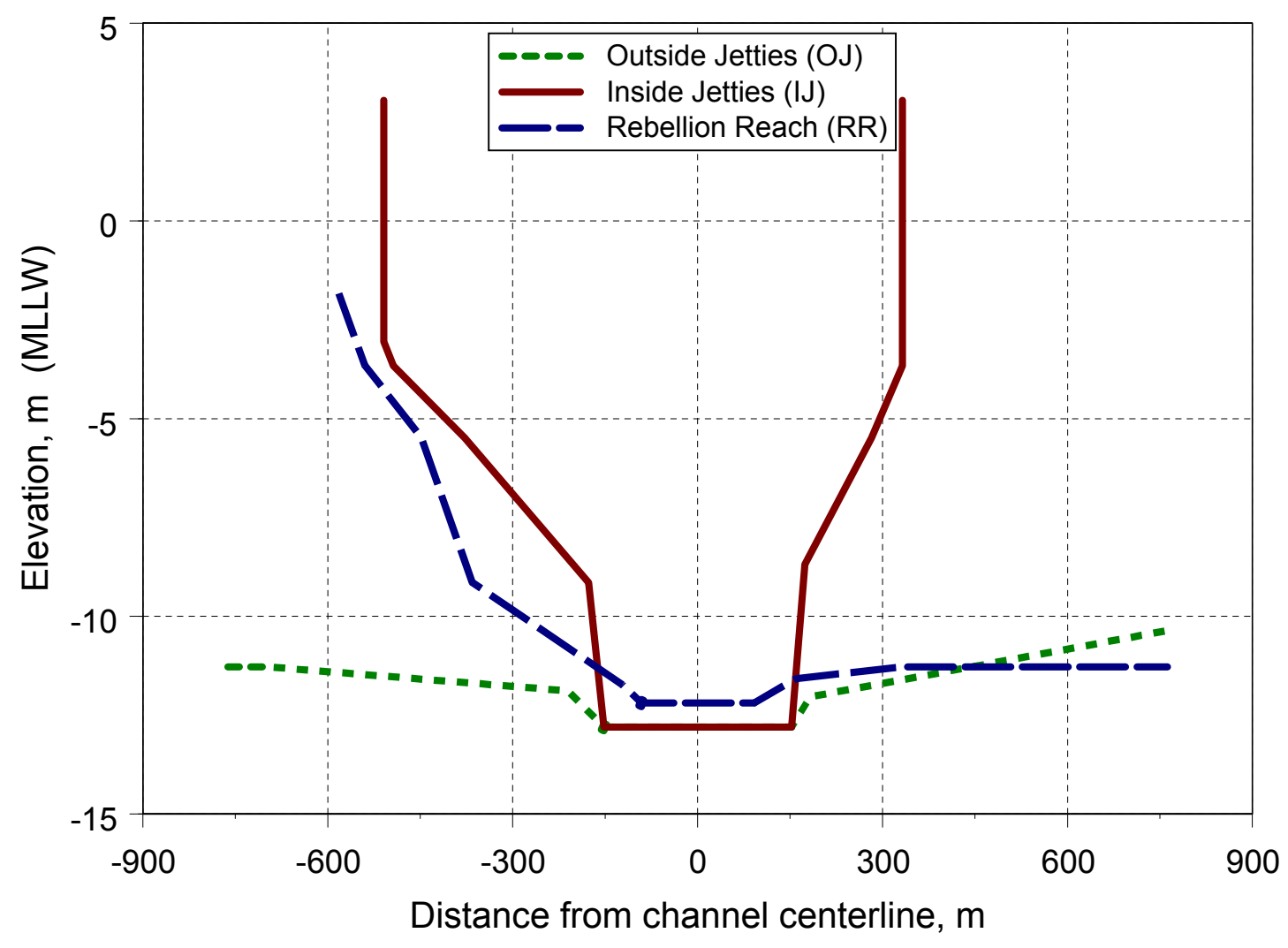

Figure 7. Cross sections as squat evaluation locations OJ, IJ, and RR

The average receiver elevations and the horizontal coordinates of the GPS receivers were used to determine the equation of a plane. The equation of this plane was used to determine the elevation at the center line of the ship at the forwardmost point on the bow and the aftmost point on the stern. The difference in elevation between the at-rest (AR) plane and the underway (UW) plane along with changes in WSE between the two plane locations were used to define the squat at the bow and stern. The equation for observed bow and stern squat from the water level, GPS, and density data is given by

$$
\text { Squat }=\left(W S E_{U W}-W S E_{A R}\right)+\left(\text { Plane }_{A R}-\text { Plane }_{U W}\right)+\left(\text { Density }_{A R}-\text { Density }_{U W}\right)
$$

To filter out some of the variability in both the ship's speed and the antenna elevations, an average for both were computed for 1 min prior to and 1 min after the point of evaluation. An "at rest" condition for each antenna was determined based on the minimum ship speed of the data. This "at rest" condition was used as the base condition to compare the antenna elevations at higher ship speeds.

GPS receiver elevations and WSE are shown in Table 3 for the six ship and location combinations that met the constant cross-section, constant speed, and antenna elevation requirements. Ship and channel input data for the empirical squat equations are shown in Table 4. Observed and predicted 


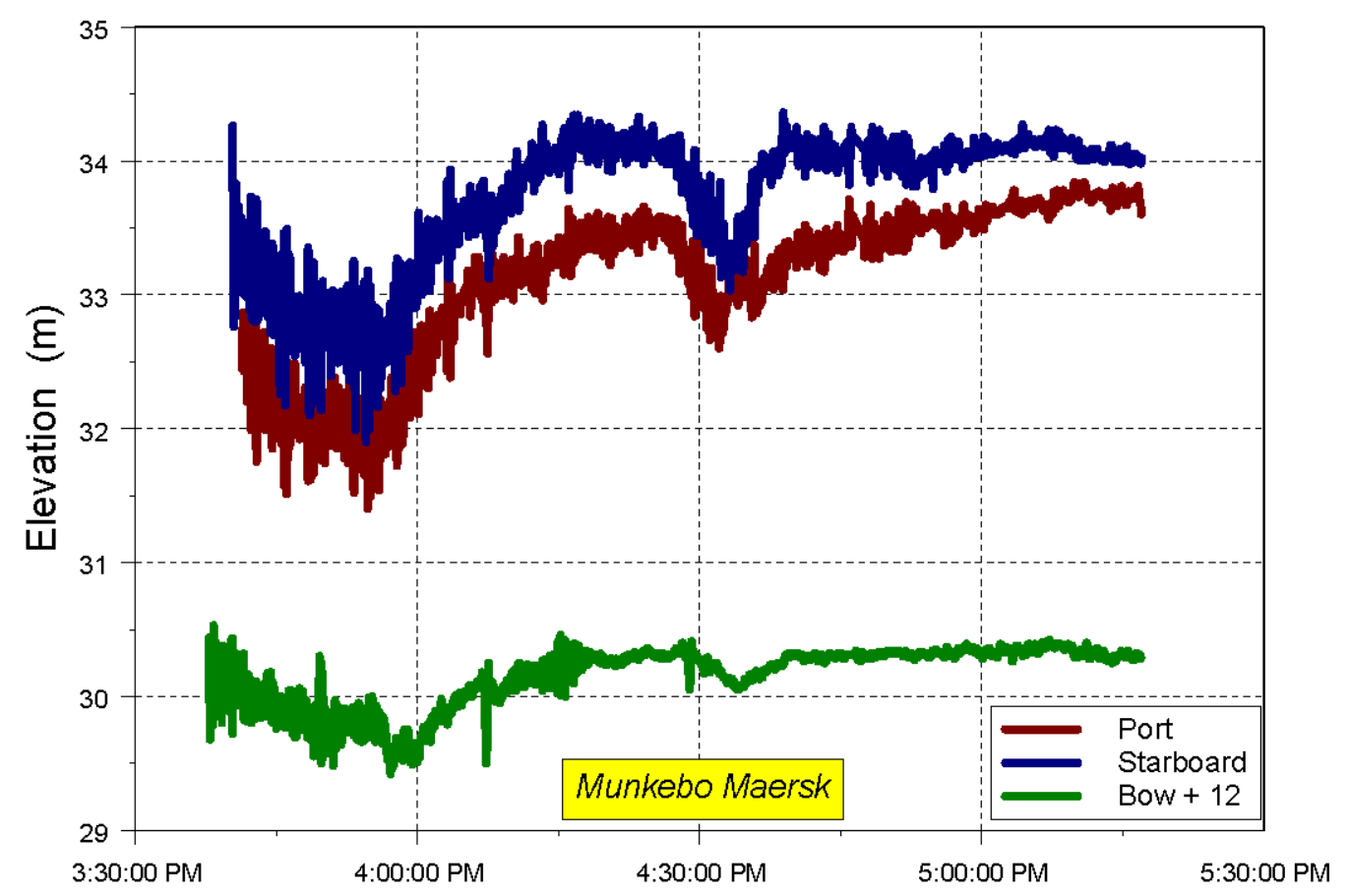

April 24, 1999

a. Inbound Munkebo Maersk

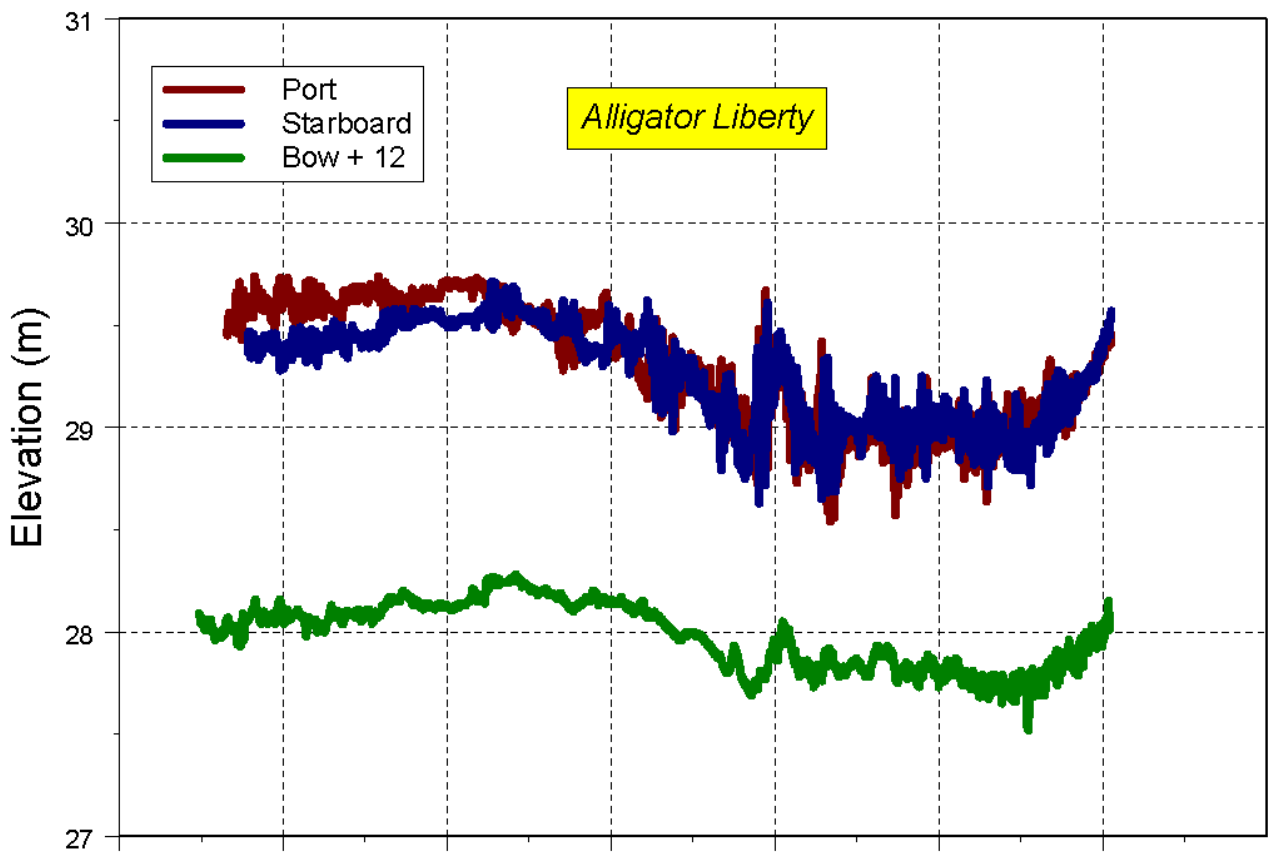

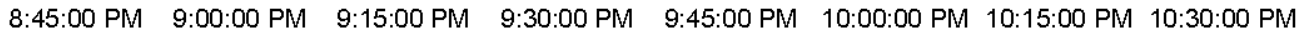
April 22, 1999

b. Outbound Alligator Liberty

Figure 8. GPS antenna elevations 
ERDC/CHL CHETN-IX-14

March 2004

\begin{tabular}{|c|c|c|c|c|c|c|c|c|c|}
\hline \multirow[b]{2}{*}{ Vessel } & \multirow[b]{2}{*}{ Location } & \multirow[b]{2}{*}{ Date } & \multirow[b]{2}{*}{ Time } & \multirow[b]{2}{*}{ WSE } & \multicolumn{3}{|c|}{ GPS Elevation, $\mathrm{m}$} & \multicolumn{2}{|c|}{ Plane El, m } \\
\hline & & & & & Bow & Port & Stbd & Bow & Stern \\
\hline \multirow[t]{3}{*}{ Alligator Liberty } & OJ & \multirow[t]{3}{*}{$4 / 22 / 03$} & $22: 11: 00$ & 0.30 & 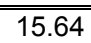 & 29.14 & 29.08 & 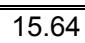 & 33.95 \\
\hline & IJ & & $21: 52: 41$ & 0.21 & 15.65 & 28.96 & 28.97 & 15.65 & 33.77 \\
\hline & $\mathrm{AR}, \mathrm{CH}$ & & $20: 58: 23$ & -0.46 & 15.90 & 29.61 & 29.39 & 15.90 & 34.41 \\
\hline \multirow[t]{2}{*}{ Ever Diamond } & OJ & \multirow[t]{2}{*}{$4 / 23 / 03$} & $13: 20: 00$ & 0.46 & 19.81 & 32.22 & 32.34 & 19.81 & 35.87 \\
\hline & AR, NC & & $15: 09: 29$ & 0.85 & 20.71 & 33.15 & 33.38 & 20.71 & 36.88 \\
\hline \multirow[t]{3}{*}{ Golden Farmer } & OJ & \multirow[t]{3}{*}{$4 / 25 / 03$} & $07: 30: 00$ & -0.09 & 11.80 & 18.62 & 18.50 & 11.80 & 19.87 \\
\hline & $\mathrm{RR}$ & & 08:05:51 & -0.11 & 11.86 & 18.67 & 18.53 & 11.87 & 19.90 \\
\hline & AR, NC & & $09: 35: 05$ & -0.06 & 12.23 & 18.71 & 18.54 & 12.23 & 19.86 \\
\hline \multirow{3}{*}{ Munkebo Maersk } & OJ & \multirow[t]{3}{*}{$4 / 24 / 03$} & $15: 54: 00$ & 0.70 & 17.62 & 32.03 & 32.67 & 17.61 & 39.96 \\
\hline & $\mathrm{RR}$ & & $16: 26: 00$ & 0.79 & 18.11 & 33.47 & 34.11 & 18.09 & 41.88 \\
\hline & AR, WR & & $17: 16: 25$ & 1.01 & 18.11 & 33.74 & 34.02 & 18.10 & 42.00 \\
\hline \multirow[t]{3}{*}{ Newark Bay } & OJ & \multirow[t]{3}{*}{$4 / 21 / 03$} & $20: 02: 00$ & -0.06 & 17.95 & 34.08 & 34.38 & 17.95 & 37.16 \\
\hline & RR & & $20: 39: 00$ & -0.03 & 18.41 & 34.63 & 34.90 & 18.41 & 37.70 \\
\hline & AR, WR & & $21: 24: 59$ & 0.30 & 18.78 & 35.06 & 35.23 & 18.78 & 38.07 \\
\hline \multirow[t]{3}{*}{ MSC Sabrina } & OJ & \multirow[t]{3}{*}{$4 / 22 / 03$} & 14:52:00 & 0.09 & 16.98 & 26.49 & 26.24 & 16.97 & 29.72 \\
\hline & IJ & & $15: 04: 29$ & 0.06 & 17.07 & 26.53 & 26.26 & 17.06 & 29.73 \\
\hline & AR, NC & & $17: 14: 59$ & -0.04 & 17.46 & 26.68 & 26.53 & 17.45 & 29.87 \\
\hline
\end{tabular}

\section{Table 4}

Ship and Channel Parameters

\begin{tabular}{|c|c|c|c|c|c|c|c|c|}
\hline Vessel & Location & $h, \mathrm{~m}$ & $L_{p p}, \mathrm{~m}$ & $T, \mathrm{~m}$ & $C_{b}$ & $V_{g}, \mathrm{~m} / \mathrm{s}$ & $V_{\text {tide, }}, \mathrm{m} / \mathrm{s}$ & $F r_{, d}$ \\
\hline \multirow[t]{2}{*}{ Alligator Liberty } & OJ & 13.8 & 230.0 & 9.9 & 0.64 & 8.4 & 0.2 & 0.739 \\
\hline & $\mathrm{IJ}$ & 13.7 & 230.0 & 9.9 & 0.64 & 7.5 & 0.6 & 0.703 \\
\hline Ever Diamond & OJ & 13.9 & 281.0 & 10.0 & 0.71 & 8.2 & -0.1 & 0.697 \\
\hline \multirow[t]{2}{*}{ Golden Farmer } & OJ & 13.4 & 178.0 & 10.1 & 0.78 & 5.8 & 0.1 & 0.515 \\
\hline & RR & 12.7 & 178.0 & 10.1 & 0.78 & 5.2 & 0.6 & 0.526 \\
\hline \multirow[t]{2}{*}{ Munkebo Maersk } & OJ & 14.2 & 280.1 & 11.0 & 0.65 & 9.4 & -0.1 & 0.786 \\
\hline & RR & 13.7 & 280.1 & 11.0 & 0.65 & 3.9 & -0.2 & 0.324 \\
\hline \multirow[t]{2}{*}{ Newark Bay } & OJ & 13.4 & 278.9 & 10.7 & 0.71 & 6.7 & -0.2 & 0.564 \\
\hline & RR & 12.8 & 278.9 & 10.7 & 0.71 & 3.9 & -0.7 & 0.288 \\
\hline \multirow[t]{2}{*}{ MSC Sabrina } & OJ & 13.6 & 224.0 & 10.9 & 0.64 & 7.4 & 0.1 & 0.654 \\
\hline & IJ & 13.5 & 224.0 & 10.9 & 0.64 & 7.3 & 0.2 & 0.646 \\
\hline
\end{tabular}

maximum squat are plotted in Figure 9 for the Huuska and Barrass formulas. Figure 10 compares the bow and stern squat measurements versus the Romisch equations. Table 5 lists the observed and predicted squat values for all cases. 


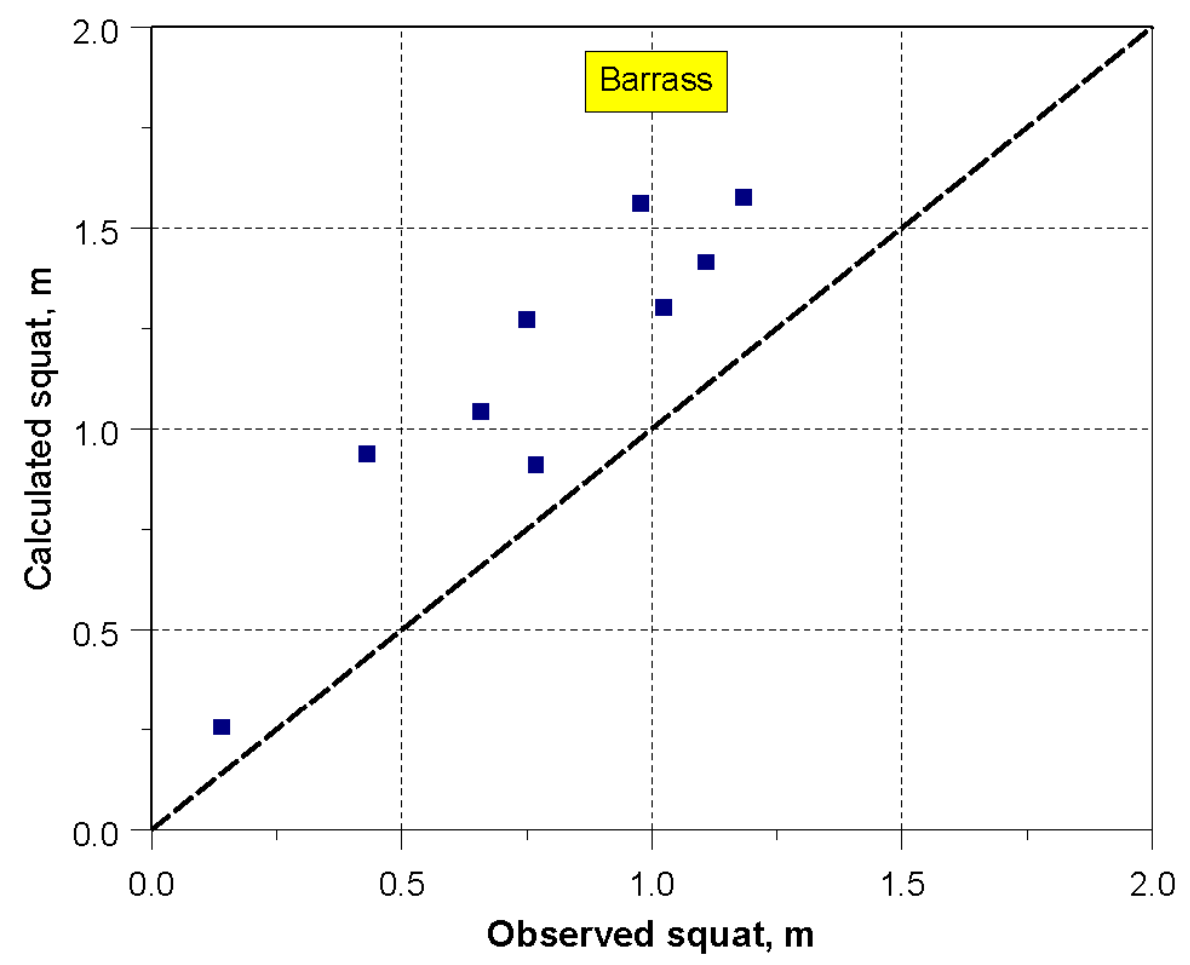

a. Barrass equation

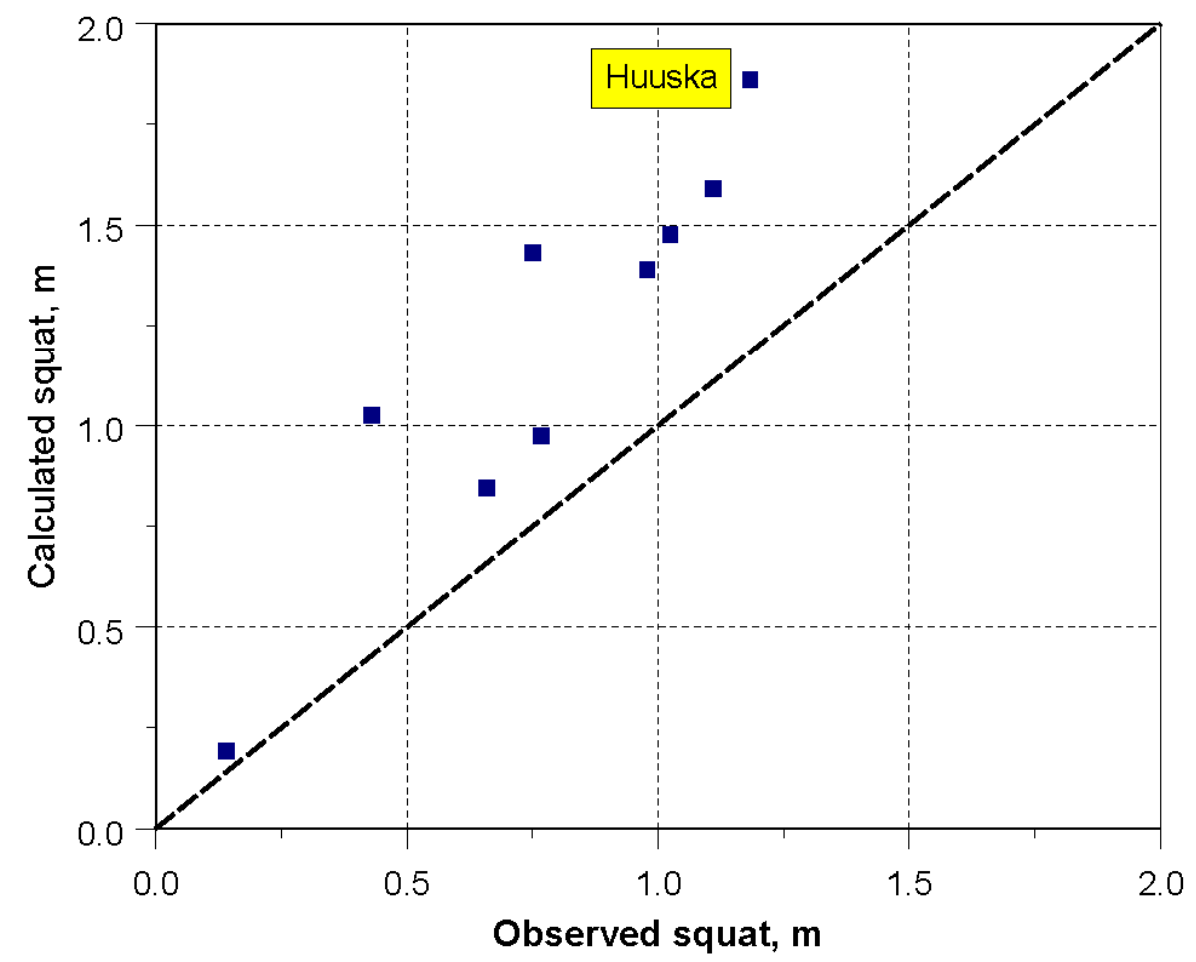

b. Huuska equation

Figure 9. Observed maximum squat 


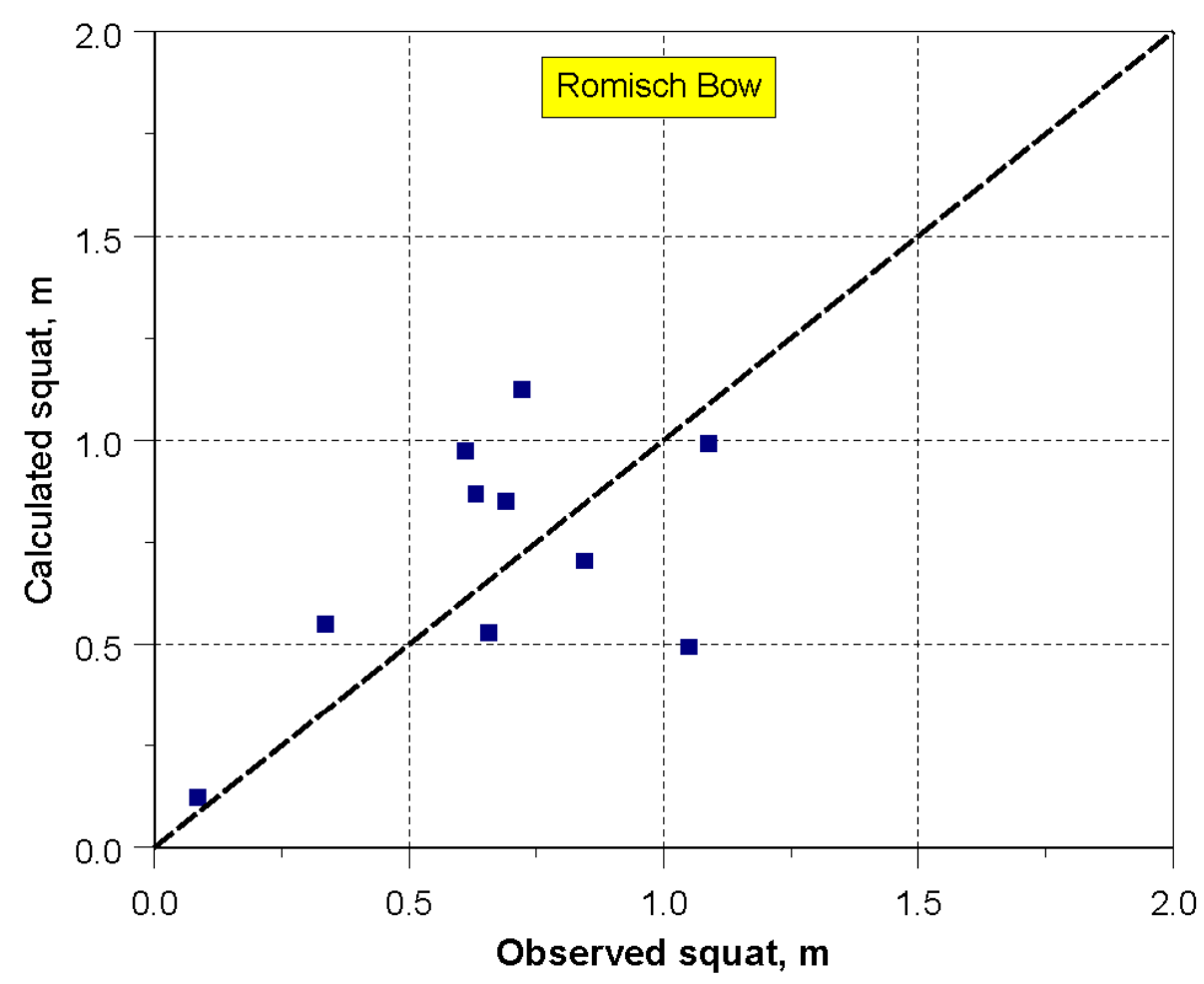

a. Bow

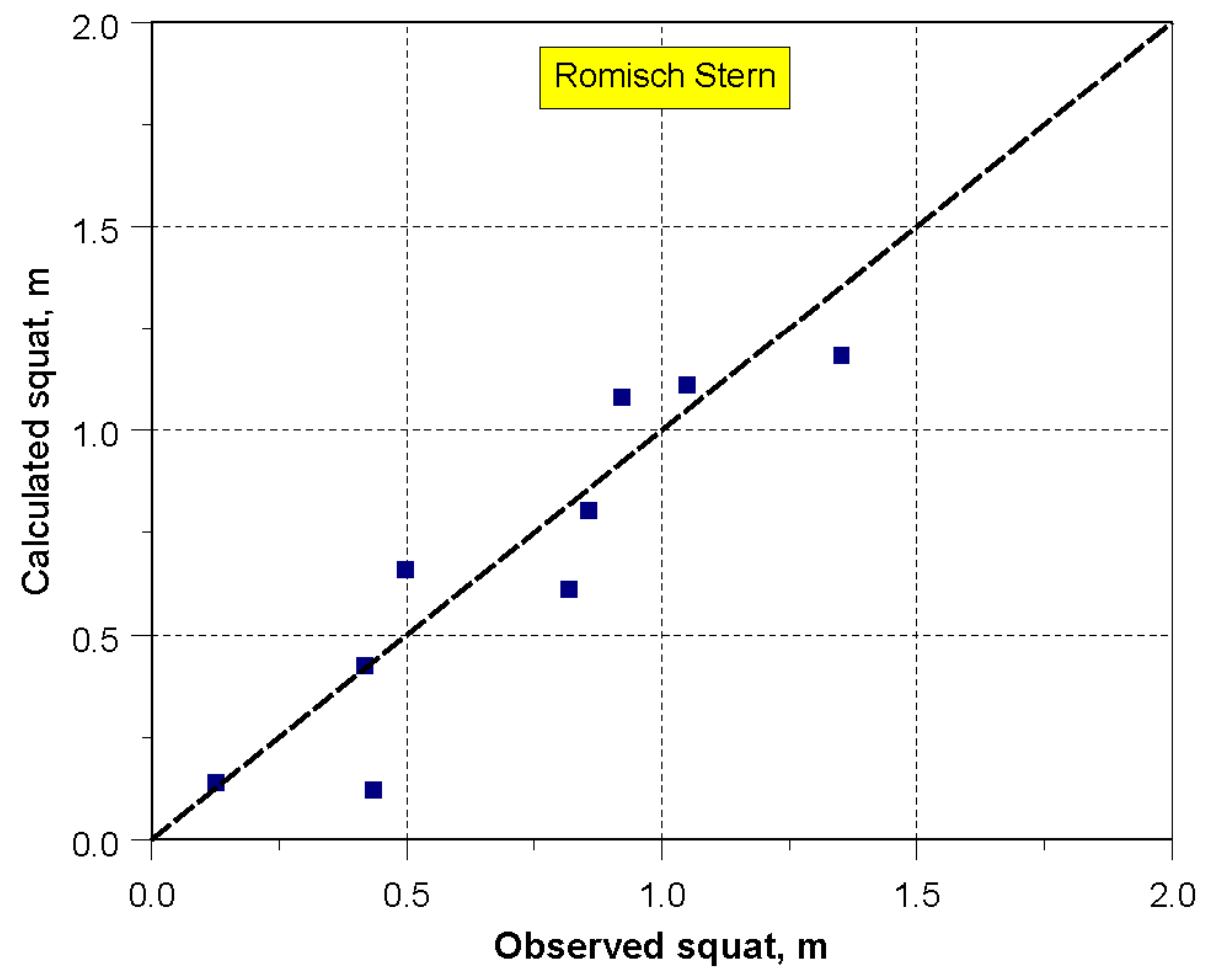

b. Stern

Figure 10. Observed versus Romisch squat 


\begin{tabular}{|c|c|c|c|c|c|c|c|}
\hline \multicolumn{8}{|c|}{$\begin{array}{l}\text { Table } 5 \\
\text { Observed and Computed Squat }\end{array}$} \\
\hline \multirow[b]{2}{*}{ Vessel } & \multirow[b]{2}{*}{ Location } & \multicolumn{2}{|c|}{ Observed, $\mathrm{m}$} & \multicolumn{4}{|c|}{ Predicted, $\mathrm{m}$} \\
\hline & & Bow & Stern & Huuska & Barrass & Rom. Bow & Rom. Stern \\
\hline \multirow[t]{2}{*}{ Alligator Liberty } & $\overline{\mathrm{OJJ}}$ & 0.99 & 1.18 & 1.86 & 1.58 & 1.09 & 1.35 \\
\hline & IJ & 0.70 & 1.11 & 1.59 & 1.41 & 0.84 & 1.05 \\
\hline Ever Diamond & OJ & 0.97 & 1.08 & 1.39 & 1.56 & 0.61 & 0.92 \\
\hline \multirow[t]{2}{*}{ Golden Farmer } & OJ & 0.87 & 0.43 & 0.98 & 0.91 & 0.63 & 0.42 \\
\hline & $\mathrm{RR}$ & 0.53 & 0.12 & 1.03 & 0.94 & 0.66 & 0.43 \\
\hline \multirow[t]{2}{*}{ Munkebo Maersk } & OJ & 0.49 & 2.05 & 2.07 & 1.97 & 1.05 & 1.88 \\
\hline & $\mathrm{RR}$ & -0.15 & -0.02 & 0.23 & 0.31 & 0.09 & 0.16 \\
\hline \multirow[t]{2}{*}{ Newark Bay } & OJ & 0.55 & 0.66 & 0.84 & 1.04 & 0.34 & 0.50 \\
\hline & $\mathrm{RR}$ & 0.12 & 0.14 & 0.19 & 0.26 & 0.09 & 0.12 \\
\hline \multirow[t]{2}{*}{ MSC Sabrina } & OJ & 1.12 & 0.80 & 1.48 & 1.30 & 0.72 & 0.86 \\
\hline & IJ & 0.85 & 0.61 & 1.43 & 1.27 & 0.69 & 0.82 \\
\hline
\end{tabular}

In general, the Barrass and Huuska equations overpredicted the observed maximum squat for all cases. The Romisch bow and stern predictions were very good, especially the stern squat predictions. A least square fit to a second order polynomial with intercept zero was calculated for each of the four squat predictors. The correlation coefficient $\mathrm{R}^{2}=0.90,0.91,0.47$, and 0.91 for the Barrass, Huuska, Romisch Bow, and Romisch Stern, respectively. Thus, the Romisch Stern is the best predictor of all the empirical equations, but the Barrass and Huuska are good from the standpoint that they are conservative since they overpredict the squat. The Huuska tends to have larger overpredictions with larger squat values, however.

SUMMARY AND CONCLUSIONS: The evaluation of squat using GPS is a significant improvement over previous techniques. GPS not only provides precise vertical and horizontal position, but also an accurate measurement of ship speed that also has been a limitation in previous studies. The speed plots show significant variation of speed along the transit. One problem that plagued previous studies and this study is the accurate determination of water level and ambient channel velocity along the path of the ship. At Charleston Harbor, the water level and velocity problems were difficult because of the semidiurnal tides up to $1.8 \mathrm{~m}(6 \mathrm{ft})$. Another concern is whether the ship takes on or discharges ballast water. Obviously, a change in the ship's draft can inadvertently affect the observed squat measurements. It is particularly important to discuss these concerns with the pilot and ship's captain and to monitor ship operations between the at-rest reference measurements and the time the measurements are taken.

When comparing squat measurements to squat prediction equations, locations along the ship channel where squat will be evaluated should be selected at a relatively uniform cross section since the empirical prediction equations are only valid under these conditions. While conducting the onboard GPS measurements, the ship operators should be asked to maintain a relatively constant speed in the preselected, constant cross-section reaches. The lack of a constant ship speed in the constant crosssection reaches eliminated a significant amount of the Charleston Harbor data from the analysis. 
In general, the measured squat in the Charleston Harbor study was consistent with PIANC (1997) empirical predictions. The Golden Farmer had the largest block coefficient $\left(C_{b}=0.78\right)$ and exhibited greater squat at the bow, in agreement with PIANC. Greater squat was observed in the stern for nine out of the other 10 ships in the study, also in agreement with PIANC for ships with smaller $C_{b}$ values. The only measured squat inconsistent with the PIANC findings was for the MSC Sabrina. Although it was a container ship with low $C_{b}$, it had greater squat at the bow.

Comparisons between the observed and predicted squat values were varied. The Barrass and Huuska equations overestimated measured squat, but this is good since the predictions are conservative. The Romisch equations for bow and stern squat provided good estimates of the observed squat, with the Romisch stern providing the best predictions of all four predictor equations. This finding is consistent with PIANC (1997). The success of the Romisch equations may be due in part to Romisch being the only one of the three equations directly including the depth/draft $(h / T)$ ratio in the prediction equation. This is probably an important parameter in the unrestricted shallow-water sites used in the Charleston Harbor analysis.

POINTS OF CONTACT: For additional information, contact Dr. Michael J. Briggs (Voice: (601) 634-2005, e-mail: Michael.J.Briggs@erdc.usace.army.mil) or Dr. Stephen T. Maynord (Voice: (601) 634-3284, e-mail: Stephen.T.Maynord@erdc.usace.army.mil).

\section{REFERENCES}

Barrass, C. B. (1979). “A unified approach to squat calculations for ships,” PIANC Bulletin , 3-10. . (1981). "Ship squat- a reply," The Naval Architect,268-272.

Eryuzlu, N. E., Cao, Y. L., and D'Agnolo, F. (1994). "Underkeel requirements for large vessels in shallow vessels in shallow waterways," $28^{\text {th }}$ International Navigation Congress, PIANC, Paper S II-2, Sevilla 1994, 17-25.

Guliev, U. M. (1971). “On squat calculations for vessels going in shallow water and through channels," PIANC Bulletin $1(7), 17-20$.

Huuska, O. (1976). "On the evaluation of underkeel clearances in Finnish Waterways," Helsinki University of Technology, Ship Hydrodynamics Laboratory, Otaniemi, Report No. 9.

ICORELS (International Commission for the Reception of Large Ships). (1980). “Report of working group IV," PIANC Bulletin 35, Supplement.

Permanent International Association of Navigation Congresses (PIANC). (1997). "Approach channels, a guide for design," Supplement to Bulletin No. 95, Brussels, Belgium.

Romisch, K. (1989). "Empfehlungen zur Bemessung von Hafeneinfahrten," Wasserbauliche Mitteilungen der Technischen Universitat Dresden, Heft 1, 39-63.

NOTE: The contents of this technical note are not to be used for advertising, publication, or promotional purposes. Citation of trade names does not constitute an official endorsement or approval of the use of such products. 